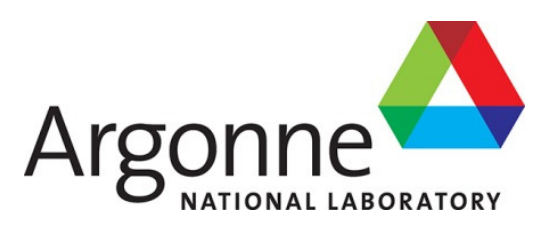

ANL 17/12

2017 Bipolar Plate Workshop Report

Chemical Sciences and Engineering Division 


\section{About Argonne National Laboratory}

Argonne is a U.S. Department of Energy laboratory managed by UChicago Argonne, LLC under contract DE-AC02-06CH11357. The Laboratory's main facility is outside Chicago, at 9700 South Cass Avenue, Argonne, Illinois 60439. For information about Argonne and its pioneering science and technology programs, see www.anl.gov.

\section{DOCUMENT AVAILABILITY}

Online Access: U.S. Department of Energy (DOE) reports produced after 1991 and a growing number of pre-1991 documents are available free via DOE's SciTech Connect (http://www.osti.gov/scitech/)

\section{Reports not in digital format may be purchased by the public from the} National Technical Information Service (NTIS):

U.S. Department of Commerce

National Technical Information Service

5301 Shawnee Rd

Alexandria, VA 22312

www.ntis.gov

Phone: (800) 553-NTIS (6847) or (703) 605-6000

Fax: (703) 605-6900

Email:orders@ntis.gov

Reports not in digital format are available to DOE and DOE contractors from the Office of Scientific and Technical Information (OSTI):

U.S. Department of Energy

Office of Scientific and Technical Information

P.O. Box 62

Oak Ridge, TN 37831-0062

www.osti.gov

Phone: (865) 576-8401

Fax: (865) 576-5728

Email: reports@osti.gov

\section{Disclaimer}

This report was prepared as an account of work sponsored by an agency of the United States Government. Neither the United States Government nor any agency thereof, nor UChicago Argonne, LLC, nor any of their employees or officers, makes any warranty, express or implied, or assumes any legal liability or responsibility for the accuracy, completeness, or usefulness of any information, apparatus, product, or process disclosed, or represents that its use would not infringe privately owned rights. Reference herein to any specific commercial product, process, or service by trade name, trademark, manufacturer, or otherwise, does not necessarily constitute or imply its endorsement, recommendation, or favoring by the United States Government or any agency thereof. The views and opinions of document authors expressed herein do not necessarily state or reflect those of the United States Government or any agency thereof, Argonne National Laboratory, or UChicago Argonne, LLC. 
ANL 17/12

\section{Bipolar Plate Workshop Summary Report}

prepared by

John P. Kopasz, Thomas G. Benjamin

Chemical Sciences and Engineering Division, Argonne National Laboratory

Deanna Schenk,

Fuel Cell Technologies Office, U.S. Department of Energy

Prepared for U.S. Department of Energy

Fuel Cell Technologies Office (FCTO) 


\section{Bipolar Plate Workshop}

Sponsored by

U.S. Department of Energy

Fuel Cell Technologies Office (FCTO)

Organized by U.S. Department of Energy and Argonne National Laboratory 


\title{
2017 Bipolar Plate Workshop Summary Report
}

\author{
Workshop held February 14, 2017 \\ USCAR \\ 1000 Town Center \#300 \\ Southfield, MI 48075 \\ Sponsored by
}

U.S. Department of Energy (DOE) - Fuel Cell Technologies Office (FCTO), Office of Energy

Efficiency and Renewable Energy (EERE)

\author{
Organized by \\ Fuel Cell Technologies Office \\ U.S. Department of Energy \\ Deanna Schenck, Fuel Cell Technologies Office, U.S. Department of Energy \\ John Kopasz, Argonne National Laboratory \\ Thomas Benjamin, Argonne National Laboratory (ANL)
}

\begin{abstract}
NOTICE
This report was prepared as an account of work sponsored by an agency of the United States government. Neither the United States government nor any agency thereof, nor any of their employees, makes any warranty, express or implied, or assumes any legal liability or responsibility for the accuracy, completeness, or usefulness of any information, apparatus, product, or process disclosed, or represents that its use would not infringe privately owned rights. Reference herein to any specific commercial product, process, or service by trade name, trademark, manufacturer, or otherwise does not necessarily constitute or imply its endorsement, recommendation, or favoring by the United States government or any agency thereof. The views and opinions of authors expressed herein do not necessarily state or reflect those of the United States government or any agency thereof.
\end{abstract}




\section{Table of Contents}

Acknowledgements 4

Executive Summary $\quad 5$

$\begin{array}{ll}\text { Workshop Agenda } & 7\end{array}$

Workshop Objectives and Organization $\quad 8$

$\begin{array}{ll}\text { Presentation Summaries } & 9\end{array}$

Opening Remarks and Workshop Overview, B. Habibzadeh, D. Papageorgopoulos, DOE $\quad 9$

Bipolar Plate Cost and Issues at High Production Rate, B. James, Strategic Analysis Inc. 11

GM Perspective on Bipolar Plate Status and Needs, B. Lakshmanan, G.M. 12

R\&D for Automotive PEM Fuel Cell System - Bipolar Plates, S. Hirano, Ford 13

Graphite-Based Bipolar Plates for PEM Motive Fuel Cell Applications, J. Norley, GrafTech 15

Corrosion Resistant Coating of Metal Bipolar Plates for PEM Fuel Cells,C.H. Wang, Treadstone 16

Modeling Performance and Stability of Bipolar Plates, R. Ahluwalia, Argonne 18

Bipolar Plate Durability Testing, R. Borup, Los Alamos 20

Forming and Manufacturing Issues in Automotive Bipolar Plate Production,

S. Farrington, AFCC

Approaches to Provide a Metallic Bipolar Plate Module to the Industry, R. Stroebel, Dana 23

Breakout Session Summaries 24

$\begin{array}{ll}\text { Materials and Coatings } & 24\end{array}$

$\begin{array}{ll}\text { Manufacturing } & 25\end{array}$

$\begin{array}{ll}\text { Modeling/Testing } & 26\end{array}$

$\begin{array}{ll}\text { Conclusions } & 27\end{array}$

$\begin{array}{ll}\text { Appendix A List of Attendees } & 30\end{array}$

Appendix B List of Acronyms $\quad 32$ 


\section{Acknowledgements}

The US DOE FCTO and ANL organizers would like to acknowledge the breakout session leaders and scribes for their help in making this a successful workshop.

\section{Breakout Session Leaders}

John Kopasz, Argonne National Laboratory

Bahman Habibzadeh, Fuel Cell Technologies Office, U.S. Department of Energy

Greg Kleen, Golden Field Office, U.S. Department of Energy

Jacob Spendelow, Los Alamos National Laboratory

Rod Borup, Los Alamos National Laboratory

Rajesh Ahluwalia, Argonne National Laboratory

\section{Scribes}

Jacob Spendelow, Los Alamos National Laboratory

Thomas Benjamin, Argonne National Laboratory

Deanna Schenck, Fuel Cell Technologies Office, U.S. Department of Energy

Eric Parker, Fuel Cell Technologies Office, U.S. Department of Energy

Shaun Onorato, Allegheny Science and Technology 


\section{Executive Summary}

The Bipolar Plate (BP) Workshop was held at USCAR ${ }^{1}$ in Southfield, Michigan on February 14, 2017 and included 63 participants from industry, government agencies, universities, and national laboratories with expertise in the relevant fields. The objective of the workshop was to identify research and development (R\&D) needs, in particular early-stage R\&D, for bipolar plates for polymer electrolyte membrane (PEM) fuel cells for transportation applications. The focus of the workshop was on materials, manufacturing, and design aspects of bipolar plates with the goal of meeting DOE's 2020 bipolar plate targets. Of special interest was the cost target of $\leq \$ 3 / \mathrm{kW}$ for the bipolar plate.

Several talks were presented on the status of bipolar plate technology. Recent cost estimates performed for DOE indicate that the BP represents from $\$ 8.23 / \mathrm{kW}$ to $\$ 8.17 / \mathrm{kW}$ or approximately $27 \%$ to $30 \%$ of the fuel cell stack cost at production rates of 100,000 and 500,000 systems per year, respectively.(1) A sensitivity analysis indicates that only catalyst cost, power density, and air management cost show a higher impact on fuel cell system cost than the BP. The cost of stainless steel (SS 316L), one of the preferred plate materials, is estimated to be $\$ 3.5 / \mathrm{kW}_{\text {net, }}$, higher than the 2020 DOE target of $\$ 3 / \mathrm{kW}$ for a finished plate.(1) Cheaper substrate materials are needed. The remainder of the bipolar plate cost is manufacturing costs (stamping/forming and joining/welding) and costs associated with the anticorrosion coating. Most metal substrates (aluminum, stainless and nonstainless steels, titanium) also require anti-corrosion coatings to prevent leaching of metal ions into the membrane, where they accelerate membrane degradation. The more expensive base materials like Ti and 316 SS provide some corrosion resistance, and pin holes or defects in the coatings are not catastrophic. However, less expensive base materials like non-stainless steels and Al are less corrosion resistant and require defect-free coatings. While current coating technology can provide the needed corrosion protection on stainless steel plates, coating deposition generally needs to occur after plate forming and is a slow process step. Coating materials and application techniques that eliminate precious metals and allow high-throughput processing are needed. Joining processes are also costly and time consuming.

Forming and manufacturing issues were discussed for metallic plates, expanded graphite/resin composite plates and compression molded particulate graphite/resin composite plates. Stretchformed coated stainless steel (CSS) foil bipolar plates cannot meet geometry targets based on optimized in-situ performance because of substrate properties and forming limitations. Carbon composite plates (either expanded graphite (EG) resin composites or bulk molded graphite composite (BMC) plates) offer lower materials cost. EG and BMC plates also offer advantages in formability and weight compared to steel plates. Corrosion for EG and BMC plates is negligible. However, EG and BMC plates have lower strength and electrical conductivity than steel plates. Composite plates in current field use are thicker than metal plates, resulting in larger stacks. Newer state-of-the-art composite bipolar plates are thinner and approaching the thickness of metal plates. Processing times for EG and BMC plates have been high, in large part due to long curing times for the resins.

The cost study (1) also revealed issues with the throughput for the manufacturing steps. Due to long cycle times, an unacceptable number of parallel processing lines would be needed to manufacture the stainless steel plates needed for the target 500,000 vehicle/year production rate using current progressive die stamping.(1) Faster production methods are needed. Hydroforming with multiple pieces per press was presented as one potential solution to increase throughput for stamping. New

${ }^{1}$ U.S. Council for Automotive Research 
joining/sealing techniques such as high throughput welding techniques for the metallic bipolar plate and other adhesion techniques to improve manufacturability also need to be developed. High-speed laser welding with multiple galvanometers was presented as one possible solution. The Workshop participants' recommended main focus areas for EG and BMC materials are high speed forming, sealing, curing, gluing \& cutting operations to meet the automotive volume and cost targets. Roller embossing and adiabatic forming have been identified as candidate high speed forming routes to 100k-500k stacks/yr. Very high density graphite parts have been demonstrated which reduce resin content, facilitating a sealing vs impregnation approach, with faster curing, enabling continuous operation.

Current internal combustion engines (IC) reach power densities of $\sim 950 \mathrm{~W} / \mathrm{kg}(2,3)$ and are expected to increase in the future (4). Fuel cell power densities must also increase to be competitive. BP channel dimensions (depth and width of the channel and radius of curvature of the bends), which can be dictated by formability of the substrate, can have a large impact on high-power performance. A primary area for R\&D is identification or development of materials that improve the forming limit. Plate designs that approach $>0.75 \mathrm{~W} / \mathrm{cm}^{2}$ total plate are important to improving FC technology competitiveness. Modeling could be helpful in identifying high performance designs and development of materials with improved forming limits. Current two-phase transport models are inadequate and improved models are needed to be able to predict performance in critical operational regimes. Models to predict plate durability are inadequate and transfer functions to move from ex-situ durability tests to in-service lifetime are absent. Current ex-situ durability tests need to be improved to more closely match real world conditions, and separate tests should be devised based on the plate material.

The two competing technologies, metallic plates and carbon composite plates, are both potential options for automotive bipolar plates. Both options have issues that need to be addressed to meet the cost and performance targets and to be manufactured at the high annual production rates needed for the automotive market. For metal plates, cheaper substrate materials with better formability are required. Manufacturing issues that need to be addressed include high-speed forming and joining. Coatings that can be stamped or formed would be beneficial. For carbon composite plates, materials or processes that lead to faster curing times are needed. . 
USCAR - 1000 Town Center Drive, Suite 300 - Southfield, Michigan 48075

Feb. $14^{\text {th }} 2017$

8:00-8:30 Registration

8:30 - 8:45 Opening Remarks and Workshop Overview Bahman Habibzadeh - DOE

8:45 - 9:00 Bipolar Plate Cost and Issues at High Production Rate

9:00 - 9:15 GM Perspective on Bipolar Plate Status and Needs Balsu Lakshmanan - GM

9:15 - 9:30 R\&D for Automotive PEM Fuel Cell System - Bipolar Plates

Shinichi Hirano - Ford

9:30-9:45 BREAK

9:45 - 10:00 Graphite-Based Bipolar Plates for PEM Motive Fuel Cell Applications-

Julian Norley - GrafTech

10:00 - 10:15 Corrosion Resistant Coating of Metal Bipolar Plates for PEM Fuel Cells-

CH Wang - TreadStone

10:15 - 11:45 BREAKOUT SESSION (Materials and Coatings)

11:45-12:15 Recap

12:15 - 1:15 LUNCH BREAK

1:15 - 1:30 Modeling Performance and Stability of Bipolar Plates Rajesh Ahluwalia - ANL

1:30-1:45 Bipolar Plate Durability Testing Rod Borup - LANL

1:45 - 2:00 Forming and Manufacturing Issues in Automotive Bipolar Plate Production

Simon Farrington -

AFCC

2:00 - 2:15 Approaches to Provide a Metallic Bipolar Plate Module to the Industry

Raimund Stroebel - Dana

2:15-2:30 BREAK

3:00-4:00 BREAKOUT SESSIONS (Manufacturing and Modeling/Testing)

4:00 - 4:30 Recap and Concluding Remarks 


\section{Workshop Objectives and Organization}

The Bipolar Plate (BP) Workshop was held at USCAR on February 14, 2017 and included 63 participants from industry, government agencies, universities, and national laboratories with expertise in the relevant fields [end users and stack assemblers, plate fabricators (forming, joining, coating), material suppliers, modelers and designers, and analysis and characterization experts]. The objective of the workshop was to identify research and development needs, primarily early-stage R\&D, for BPs for PEM fuel cells for transportation applications. The focus of the workshop was on materials, manufacturing and design aspects of BPs with the goal of meeting DOE's 2020 BP targets. Of special interest was the cost target of $\leq \$ 3 / \mathrm{kW}$ for the BP.

The workshop was organized to provide presentations by topical experts followed by breakouts of smaller groups for discussions to allow attendees to provide their input and expertise. Morning presentations included BP status versus DOE targets (Dimitrios Papageorgopoulos and Bahman Habibzadeh, DOE); BP cost estimates (Brian James, Strategic Analysis, Inc.); automotive perspectives on BP status and needs (Balsu Lakshmanan, GM, and Shinichi Hirano, Ford); graphite-based BPs (Julian Norley, GrafTech); and corrosion-resistant metal BPs BP( CH Wang, Treadstone Technologies, Inc.). These presentations were followed by breakout sessions on BP materials and coatings. Four parallel sessions were organized to ensure active involvement of workshop participants. Following the breakout sessions, each breakout group provided a short summary of their session to all of the workshop attendees.

Afternoon presentations focused on modelling BP performance and stability (Rajesh Ahluwalia, ANL); BP durability testing (Rod Borup, LANL); forming and manufacturing issues (Simon Farrington, AFCC); and approaches to joining and sealing (Raimund Stroebel, Dana Corp.). These presentations were followed by four breakout sessions: two sessions discussing modeling and testing and two sessions discussing manufacturing issues. The workshop ended with a representative from each afternoon breakout group summarizing the outcome of the discussions to all of the workshop participants. Overviews of the presentations and a discussion of the outcomes from the breakout groups follow. Copies of the presentations can be found at https://energy.gov/eere/fuelcells/downloads/researchand-development-needs-bipolar-plates-pem-fuel-cell-technologies. 


\section{Opening Remarks and Workshop Overview (Dimitrios Papageorgopoulos and Bahman Habibzadeh, DOE/FCTO)}

This is an exciting time for the fuel cell industry. The fuel cell community has made significant advances and the market is growing, with an average annual growth in fuel cells shipped since 2010 of about $30 \%$, and over 60,000 units shipped in 2015 . Commercial fuel cell vehicles are now available, with more than 1,100 fuel cell vehicles on the road in US Today (Feb. 2016). Fuel cell costs must be reduced further in order to effectively compete with the incumbent technologies in the marketplace and enable widespread commercialization of hydrogen and fuel cell technologies. Current (2016) cost estimates put automotive fuel cell system costs at $\sim \$ 53 / \mathrm{kW}$ at a production rate of 500,000 systems/year (and \$60/kW at 100,000 systems/year), compared to DOE's ultimate cost target of $\$ 30 / \mathrm{kW}$. One of the main contributors to fuel cell stack cost is the cost of the BPs, which accounts for $\sim 30 \%$ of the stack cost. BP costs are currently dominated by commodity materials costs, and are relatively insensitive to manufacturing volume.

The DOE has developed targets for fuel cell systems and components based on performance and costs needed to be competitive with incumbent technologies. The BP targets developed for DOE's 2016 Multi-Year Research, Development, and Demonstration Plan are presented in Table 1.(5) While most of the technical targets have been achieved, further R\&D is needed to meet cost and durability targets.

Table 1

Table 1 Technical Targets: Bipolar Plates for Transportation Applications

\begin{tabular}{|c|c|c|c|}
\hline Characteristic & Units & 2015 Status & 2020 Targets \\
\hline Cost $^{a}$ & $\$ / \mathrm{kW}_{\text {net }}$ & $7^{b}$ & 3 \\
\hline Plate weight & $\mathrm{kg} / \mathrm{kW}_{\text {net }}$ & $<0.4^{c}$ & 0.4 \\
\hline $\begin{array}{l}\text { Plate } \mathrm{H}_{2} \text { permeation } \\
\text { coefficient }^{d}\end{array}$ & $\begin{array}{l}\text { Std } \mathrm{cm}^{3} /\left(\sec \mathrm{cm}^{2} \mathrm{~Pa}\right) \\
@ 80^{\circ} \mathrm{C}, 3 \mathrm{~atm} 100 \% \mathrm{RH}\end{array}$ & $0^{e}$ & $<1.3 \times 10^{-14, f}$ \\
\hline Corrosion, anode & $\mu \mathrm{A} / \mathrm{cm}^{2}$ & No active peak ${ }^{h}$ & $<1$ and no active peak \\
\hline Corrosion, cathode & $\mu \mathrm{A} / \mathrm{cm}^{2}$ & $<0.1^{\mathrm{c}}$ & $<1$ \\
\hline Electrical conductivity & $\mathrm{S} / \mathrm{cm}$ & $>100^{j}$ & $>100$ \\
\hline $\begin{array}{l}\text { Areal specific } \\
\text { resistance }^{k}\end{array}$ & ohm cm² & $0.006^{\mathrm{h}}$ & $<0.01$ \\
\hline Flexural strength' & $\mathrm{MPa}$ & $>34{\text { (carbon plate })^{\mathrm{m}}}$ & $>25$ \\
\hline Forming elongation ${ }^{n}$ & $\%$ & $20-40^{\circ}$ & 40 \\
\hline
\end{tabular}

a Costs projected to high volume production $(500,00080 \mathrm{~kW}$ systems per year), assuming MEA meets performance target of $1,000 \mathrm{~mW} / \mathrm{cm}^{2}$.

b Cost when producing sufficient plates for 500,000 systems per year. DOE Hydrogen and Fuel Cells Program Record 15015, "Fuel Cell System Cost-2015.” http://www.hydrogen.energy.gov/program records.html.

c C.H. Wang (Treadstone), "Low-cost PEM Fuel Cell Metal Bipolar Plates," 2012 Annual Progress Report, http://www.hydrogen.energy.gov/pdfs/progress12/v_h_1_wang_2012.pdf. 
Per the standard gas transport test (ASTM D1434).

e C.H. Wang (Treadstone), private communication, October 2014.

f Blunk, et al, J. Power Sources 159 (2006) 533-542.

g $\quad \mathrm{pH} 30.1 \mathrm{ppm} \mathrm{HF}, 80^{\circ} \mathrm{C}$, peak active current $<1 \times 10^{-6} \mathrm{~A} / \mathrm{cm}^{2}$ (potentiodynamic test at $0.1 \mathrm{mV} / \mathrm{s},-0.4 \mathrm{~V}$ to $+0.6 \mathrm{~V}(\mathrm{Ag} / \mathrm{AgCl}$ )), de-aerated with Ar purge.

h Kumar, M. Ricketts, and S. Hirano, "Ex-situ evaluation of nanometer range gold coating on stainless steel substrate for automotive polymer electrolyte membrane fuel cell bipolar plate,” Journal of Power Sources 195 (2010): 1401-1407, September 2009.

i $\mathrm{pH} 30.1 \mathrm{ppm} \mathrm{HF}, 80^{\circ} \mathrm{C}$, passive current $<5 \times 10^{-8} \mathrm{~A} / \mathrm{cm}^{2}$ (potentiostatic test at $+0.6 \mathrm{~V}(\mathrm{Ag} / \mathrm{AgCl}$ ) for $>24 \mathrm{~h}$, aerated solution.

j O. Adrianowycz (GrafTech), "Next Generation Bipolar Plates for Automotive PEM Fuel Cells," 2009 Annual Progress Report, http://www.hydrogen.energy.gov/pdfs/progress09/v_g_2_adrianowycz.pdf.

k Includes interfacial contact resistance (on as received and after potentiostatic test) measured both sides per Wang, et al. $\mathrm{J}$. Power Sources 115 (2003) 243-251 at $200 \mathrm{psi}\left(138 \mathrm{~N} / \mathrm{cm}^{2}\right)$.

1 ASTM-D 790-10 Standard Test Method for Flexural Properties of Unreinforced and Reinforced Plastics and Electrical Insulating Materials.

m D. Haack et al. (Porvair), "Carbon-Carbon Bipolar Plates,” 2007 Annual Progress Report, http://www.hydrogen.energy.gov/pdfs/progress07/v_b_3_haack.pdf.

n Per ASTM E8M-01 Standard Test Methods for Tension Testing of Metallic Materials, or demonstrate ability to stamp generic channel design with width, depth, and radius.

o M. Brady et al. (Oak Ridge National Laboratory), "Nitrided Metallic Bipolar Plates," 2010 Annual Progress Report, http://www.hydrogen.energy.gov/pdfs/progress 10/v_1_1_brady.pdf.

The DOE has previously funded and continues to support projects to improve BP performance and durability and reduce cost. Some of the previous projects include carbon based plates [Development of a \$10/kW Bipolar Separator Plate , IGT(6), Economical High Performance Thermoplastic Composite Bipolar Plates, NanoSonic Inc.,(7) ;Next Generation Bipolar Plates for Automotive PEM Fuel Cells, GrafTech Int. Ltd. (8) \}and development of corrosion resistant coatings for metallic plates [Development of Corrosion-Resistant Coatings for Fuel Cell BPs, (Physical Sciences Inc. (1999)(9); Nitrided Metallic BPs, ORNL (10); Metallic BPs with Composite Coatings, ANL (11)); and Low-Cost PEM Fuel Cell Metal BPs, TreadStone Technologies Inc. (12))]. Currently, DOE is funding efforts investigating corrosion resistant coatings of metallic plates (Novel Structured Metal Bipolar Plates for Low Cost Manufacturing by TreadStone, an active BPP project as described later in this report (13).

The objective of this workshop is to identify R\&D needs for BPs for PEM fuel cells for transportation applications. Research priorities will be identified and articulated in terms of short-term vs. long-term $R \& D$ and the roles and extent of support of industry, government, national laboratories, and academia in achieving the targets need to be defined. The focus is on materials, manufacturing and design aspects of BPs with the goal of meeting DOE's 2020 technical and economic BP targets. The technical targets are shown above and include high electrical conductivity, low gas permeability, high corrosion resistance, high flexural strength, and good forming elongation. The economic target includes materials and manufacturing costs. Other properties that must be considered include thermal conductivity, chemical stability, hydrophobicity/hydrophilicity, and thermal expansion. 


\section{Bipolar Plate Cost and Issues at High Production Rate (Brian James, Strategic Analysis, Inc.)}

Strategic Analysis, Inc. (SA) has performed Design for Manufacturing and Assembly (DFMA) cost analyses of $80 \mathrm{~kW}_{\mathrm{e}}$ (auto) and $160 \mathrm{~kW}$ (bus) fuel cell systems for DOE. As part of these studies, they have analyzed BP production, assessing processing options for cost and logistics, including options such as batch processing vs. continuous, welding vs. adhesives, coating before or after forming, press forming vs hydro-forming, etc. These assessments include cycle time, dimensional tolerances, and capital requirements. The 2016 estimate for an $80 \mathrm{~kW}$ automotive fuel cell system is $\$ 53 / \mathrm{kW}_{\text {net }}$ at a production volume of 500,000 vehicles/year.(1) SA's current cost estimates are based on stainless steel (SS) 316L metal plates formed by progressive stamping. The plates are laser welded and coated by Treadstone's physical vapor deposition (PVD) process. Their results indicate that the BP represents $\mathrm{t} \$ 8.17 / \mathrm{kW}$ for production volumes of 500,000 systems/year, $\$ 8.23 / \mathrm{kW}$ for 100,000 systems/year, and $\$ 9.65 / \mathrm{kw}$ at 10,000 systems/year. This accounts for approximately $15 \%$ of the automotive fuel cell system cost at 500,000 systems per year ( $30 \%$ of the stack cost), and $11 \%$ of the total system cost for $10 \mathrm{k}$ systems per year ( $20 \%$ of stack cost). The cost of the plate material, SS $316 \mathrm{~L}$, is estimated to be $\$ 3.5 / \mathrm{kW}_{\text {net }}$, higher than the target of $\$ 3 / \mathrm{kW}$ for a finished plate.

SA has also asked original equipment manufacturers (OEMs) and suppliers for cost estimates, in order to compare to their cost estimate. There was an order of magnitude difference at a production volume of 100,000 vehicles per year, with the reported costs ranging from $\sim \$ 7 / \mathrm{kW}$ to $\sim \$ 90 / \mathrm{kW}$ per year. The cost uncertainty may stem from misalignment of reporting, including whether cost includes forming, coating, joining, gaskets, whether it is for BP or BP assembly, whether cost is truly based on high production rate machinery, etc. Important cost factors include power density, ratio of active to total area, and plate design, which impacts available forming, joining, and coating technologies.

SA estimates that for the process line modeled for the cost estimate (5-stage progressive stamp followed by quality control then laser welding of singulated parts, then PVD coating) between 110 and 30 parallel processing lines (if run 24 hours per day and 7 days per week and no roll change out time allotted) would be needed to reach the 500,000 vehicle/year production rate. DOE's project with GLWN reported that Interviewees stated that parallel production lines are undesirable/unacceptable due to quality control concerns. This means that a faster process is needed. Other issues with progressive die stamping were identified and include difficulties maintaining flatness for laser welding, difficulties with the $\pm 5 \mu \mathrm{m}$ tolerances, slow cycle times ( $2.5 \mathrm{sec} /$ plate), high capital cost ( $\$ 1000 /$ ton), high tooling cost ( $>600 \mathrm{k}, 100$ s of hours to fabricate), and limitations on BPP geometry due to wall thinning. SA has investigated hydroforming as an alternative to progressive die stamping.

Hydroforming would require forming multiple parts simultaneously to meet capacity requirements. Hydroforming 4 parts simultaneously would still require more than 70 manufacturing lines. Hydroforming would also require a separate stamping to cut manifold holes and separate the parts.

The coating step was also investigated. Several different coating technologies have been investigated in the literature, including sub-atmospheric/vacuum deposition [TreadStone DOTS \& TiOx (PVD process), Impact Coating (PVD), PECVD Amorphous Carbon (on Ti plates for Toyota)], atmospheric deposition [Nitriding (ORNL)], liquid processes [pickling, polymer matrix (Dana Reinz patents*(14))], and utilizing special custom alloys with innate corrosion resistance. Issues with coatings include potentially long cycle time ( 2- 30 minutes), whether the coating is applied in a batch vs. continuous process, and the size of the batch (1's to 100 's of parts). The costs of sputtering targets can be an issue for sputter depositions, as the cost of targets can add a substantial cost beyond the material price. 
SA also addressed BPP joining issues. Laser welding and adhesive joining were discussed. The cost of laser welding is highly dependent on welding length and assumptions on how much of the BPP area is welded to connect the BPPs for electrical contact. Welding speed can be high for thin parts, but welding time is still 0.2-5 min/BPP assembly due to the long weld lengths required. Engineering solutions can be deployed to increase throughput, including utilizing multiple lasers per station, multiple galvanometers per laser, and multiple stations. Using these approaches, welding times can be reduced to $\sim 2$ seconds/BPP assembly, although such short times have not yet been demonstrated due to lack of high volume demand. An alternative approach is to use adhesive bonding of the plates, as used by Toyota in the Mirai. The adhesive bonding process can be done roll-to-roll before part singulation with projected processing speeds of $<2$ /BP assembly at line speeds of $20 \mathrm{~m} / \mathrm{min}$. The down side is that seals can fail more frequently than experienced for welding.

Based on industry input, only 3-5 suppliers worldwide are currently capable of producing BPs with the quality and reliability required by OEMs at high volume. While stamping and welding technologies are (in many ways) mature, achieving the required precision, quality control, and volume production dramatically limits the number of suppliers. New production houses can be developed but it will require years to establish themselves as viable and reliable automotive suppliers. A key point is the generation of geometry-neutral plate processing technologies to fully realize economies of scale.

The DOE FCTO-funded projects by SA and GLWN suggest several opportunities for advancement of BP production as summarized below. Development of (near-) continuous, roll-to-roll high-speed processes ( $<1 \mathrm{sec} /$ plate) for BP fabrication would reduce processing time and cost. Characterization and assessment of thinning of metal in BP during forming would provide insight into acceptable forming technologies for candidate plate metals and insight into limitations of conventional sheet metal stamping due to metal elongation limits and thinning. Development of alternative forming techniques that solve the metal thinning limitations of conventional stamping would also be beneficial. Solutions to these issues would support advanced BPP designs consistent with expected future stack performance (high power density, improved water management, low-pressure drop, and low stoichiometric flow rates).

Demonstration of high-speed, high accuracy, geometry-neutral fuel cell stack assembly systems and BPP welding would overcome issues with current systems that are costly due to low welding and indexing speeds.

\section{GM Perspective on Bipolar Plate Status and Needs (Balsu Lakshmanan, GM)}

GM has demonstrated real world experience in full fuel cell vehicles, and has accumulated 3 million miles total with individual vehicles approaching 150,000 miles including 8 winter cycles. GM believes adequate durability has been achieved for commercial entry of FCVs. However, cost reductions along with increases in power density are necessary to be competitive in the future. Current IC engines reach specific power of $\sim 950 \mathrm{~W} / \mathrm{kg}(2,3)$ and are expected to increase in the future (4). To be competitive, GM believes fuel cell specific power must also increase.

GM believes a successful R\&D approach must account for interactions from materials to systems. For automotive fuel cells these interactions include materials-cell, cell-stack, stack-fuel cell system, and fuel cell system-fuel cell propulsion system interactions. In other words, materials issues may be alleviated by changing operating conditions or the properties of surrounding components. However, not all of these areas fall into the "precompetitive" research arena. Fuel cell propulsion system and fuel cell system work is a competitive research area, while large active area cells to stacks should be considered areas for collaborative advanced engineering. Pre-competitive research is limited to 
research on basic principles, new technology or proof-of-concepts and laboratory demonstrations up to $\sim 50 \mathrm{~cm}^{2}$ MEAs. Looking at this from a Technology Readiness Level (TRL) perspective, GM suggests DOE support is appropriate for pre-competitive TRL-4 and below. The fuel cell community needs to collaborate up to TRL 3 (In situ single cell non-stack footprint $\sim 50 \mathrm{~cm}^{2}$ ). The estimated timeframe for a new material to reach final product after TRL-4 proof-point could be 5 to 8 years. TRL 5-7 is appropriate for collaborative advanced engineering, and TRL 8-9 is competitive product development. Work on new flow fields and stamping could fall into Full-Scale Demonstration (TRL-5) and Demonstration in Relevant Environment (TRL-6) and may not be pre-competitive.

TRL-3 $\left(50 \mathrm{~cm}^{2}\right.$ or sub-scale fuel cell hardware) work for the BP is critical for achieving stack level targets for power density and specific power. Incumbent technologies such as hybrids and new energy vehicles like battery electric vehicles (BEVs) are getting cheaper and getting there faster due to economies of scale. FC stack targets should be revisited to remain competitive. Specifically, the BP cost target should be reduced from $\$ 3 / \mathrm{kW}$ to $\$ 2 / \mathrm{kW}$, the plate weight per unit power from $0.4 \mathrm{~kg} / \mathrm{kW}$ to $0.15 \mathrm{~kg} / \mathrm{kW}$, and flexural strength from $>25 \mathrm{MPa}$ to $>60 \mathrm{MPa}$. Research focused on developing new substrates and coatings can enable high power density plates. The other BP targets would be unchanged. Plate designs that approach $>0.75 \mathrm{~W} / \mathrm{cm}^{2}$ total plate area (active plus inactive) are important to improving FC technology competitiveness.

\section{R\&D for Automotive PEM Fuel Cell System - Bipolar Plates (Shinichi Hirano, Ford)}

At high production volumes, catalysts and BPs are the two highest cost components based on the DOE funded fuel cell cost analysis (1). A fuel cell system costs are sensitive to BP costs, with only catalysts cost, power density, and air loop cost showing a higher impact. To meet fuel cell cost targets, BP cost reductions, including reduction for materials cost and for the cost of the manufacturing process, are required.

The basic functions of a BP are to collect current, separate the gases, provide reactant gas flow fields for the fuel and air, and provide mechanical support for stack. The basic requirements are that the plate provide good electrical conductivity, good thermal conductivity, be chemically stable, be resistant to corrosion, be a gas barrier, be manufacturable, and retain these properties under fuel cell operating conditions. The BP must also meet cost requirements. The existing DOE targets (shown above in Table 1) cover the technical attributes for precompetitive research. Testing protocols associated with this target table are under conditions that mimic stack conditions. For example, area specific resistance (ASR) measurements are performed under compression and using a surrogate GDL. The resistance value is corrected for the GDL only resistance to obtain GDL free values as the ASR. The DOE target describes ex-situ corrosion tests. They are potentiodynamic for anode corrosion $(0.1 \mathrm{mV} / \mathrm{s}$, -0.4 to $+0.6 \mathrm{~V}(\mathrm{Ag} / \mathrm{AgCl}$ ) and potentiostatic for cathode corrosion (at $0.6 \mathrm{~V}(\mathrm{Ag} / \mathrm{AgCl})$ for $>24$ hours). However, these ex-situ corrosion tests are recommended just for reference, not as a material pass/fail criterion, because measured current may include other than the corrosion current and/or these test conditions do not necessarily represent all stressors for BP corrosion. Real-world voltages may exceed those indicated in the current BP testing. Higher potentials can exist during startup/shutdown and during fuel starvation events. $(15,16,17)$. Further ex-situ corrosion tests are recommended to evaluate corrosion resistance of BP materials to help understand material characteristics under real world conditions. In addition to current corrosion tests, potentiodynamic tests with wider potential range, including higher potentials as mentioned above, are recommended. In-situ durability tests are imperative to verify material durability, including measurements of leached ions. The existing DOE targets are focused on directing precompetitive research projects toward needed areas of improvement. They do not address product specifications and are not sufficient to design BPs for commercial products. 
Ford evaluated various BP materials that have demonstrated potential to provide corrosion resistance and retention of electrical conductance, including Au nanoclad ${ }^{\circledR}$, nanometer scale Au coating on stainless steel foil supplied by Daido Steel and Au dot coatings on the metal oxide coated stainless steel foil, supplied by TreadStone. The Au dot coating technology demonstrated a corrosion current less than $2 \mu \mathrm{A} / \mathrm{cm}^{2}$ at both $0.5 \mathrm{~V}$ and $1.6 \mathrm{~V}$. Au nanoclad ${ }^{\circledR}$ coating demonstrated no significant increase in ASR during in-situ durability tests and showed no detectable metal cations in the effluent water (using ICP analysis). Another coating technology being investigated is multilayer Au-Ti coatings. They can significantly reduce the amount of Au in the coating. Auger Electron Spectroscopy (AES) analysis showed these coatings retained their layered structure after potentiostatic corrosion testing. (18)

Dimensions of flow field gas channels can have a large impact on high-power performance. For example, narrowing channel span dimensions from $1.5 \mathrm{~mm}$ to $0.8 \mathrm{~mm}$ enabled the use of less stiff GDLs, which had better performance at high current densities (19). Improving the materials' forming limit can increase the design space of flow field configurations and may lead to better performance.

There are two major precompetitive R\&D needs for metallic BP materials. One is to improve the forming limit of the substrate materials (thin metallic foil). The other is to develop robust coating materials for metallic BPs. In particular, coatings are needed that 1 ) enable pre-forming deposition process (coat before the forming) and mitigate coating defects, such as cracks or delamination, during the stamping process, (2) provide self-protection from corrosion/degradation at coating defect areas, (3) provide chemical stability, particularly mitigate leaching of metal ions which are harmful for other components, e.g. the membrane, (4) eliminate PGMs or precious metal for lower cost, and (5) are amenable to high-throughput manufacturing process. The ideal solution is a low-cost, highly formable metal substrate that can provide corrosion resistance without a coating, (e.g. through surface modification).

A second area for precompetitive $R \& D$ is for the manufacturing process. A common numerical forming model for metallic BPs is required in order to optimize process parameters to improve the forming limit. The model should be validated with various forming methods and substrate materials. Mechanistic understanding of two-phase fluid flow in the BP flow field is imperative to design the BP. A common numerical model of flow field water management is required. Last, a high throughput joining method is necessary, e.g. fast welding technique or glue adhesion for metallic BPs.

New concepts for the flow field need to be identified and feasibility established. For example, a foam flow field may offer advantages to solve two-phase flow imitations for metallic BPs, e.g. plates that wick water away from the GDL/plate interface. Finally, a fundamental understanding of the technical limitations of various BP materials, including carbon composite and metallic plates is valuable.

Developing an understanding of the technical limitations should include an investigation of the suitability for various application/operating conditions for various BP materials.

\section{Graphite-Based Bipolar Plates for PEM Motive Fuel Cell Applications (Julian Norley, GrafTech)}

Advanced Energy Technologies LLC is a subsidiary of GrafTech International, a 100-year old company. They are manufacturers of flexible graphite materials for electronic and thermal management, fluid sealing, automotive gasketing, fire retardancy and fuel cell applications. 
Expanded graphite (EG) materials are derived from naturally occurring flake graphite that is chemically intercalated and then heated to expand the graphite. The expanded graphite is pressed into a mat form. The mat blank is then compression molded into a half-plate comprising gas and coolant channels The graphite preform is then impregnated with resin and cured to form the finished halfplate. Fuel and oxidant half-plates are adhesively bonded and cured to form the finished BP. Because EG materials retain the anisotropic structure of the starting flake, in-plane (xy) and through-plane (z) properties are very different. Expanded graphite materials involve a continuous graphite phase that results in higher in-plane thermal electrical conductivity than bulk molded compounds but lower through-plane properties. The higher thermal conductivity can be exploited in higher current density designs. Compared to steel, EG exhibits lower density, strength, and through-plane electrical conductivity. Corrosion is negligible. EG plates are used in Ballard's current generation FCveloCity ${ }^{\circledR}$ modules for bus applications. More than 1,000,000 BPs have been produced and more than 10 million $\mathrm{km}$ of road service in bus and automotive applications and millions of hours of run time in forklift applications have been demonstrated since 2000. EG plates in current field use have a BP thickness of $\sim 2.0 \mathrm{~mm}$ and a web thickness of $\sim 0.45 \mathrm{~mm}$, while those developed under a previous DOE project at GraphTec (DE-FC36-07G017012 have a BP thickness of $1.6 \mathrm{~mm}$ and minimum web thickness of 0.32 $\mathrm{mm}$. The state-of-the-art thickness for EG plates is $~ 1.1 \mathrm{~mm}$ BP thickness and a minimum web thickness of 0.15-0.2 mm. EG plates also offer potential for more complex flow field designs compared to corrugated metal plates.

Bulk molded/filled/particulate graphite composite materials (BMC) use bulk-molding compounds that comprise high loadings (77-87 wt\%) of natural and synthetic graphite particulates and carbon fibers in thermoset resins. Plates are typically compression molded with typical times of $\sim 1-5$ minutes at temperatures of $150-180^{\circ} \mathrm{C}$ at $20-50 \mathrm{MPa}$. BMC plates have been used successfully in motive applications since 2005 and are favored for thicker plates/stationary power applications. Several suppliers of bulk molding compounds and finished plates are known (but not named herein). BP web thicknesses similar to expanded graphite materials are realized ( $1.5 \mathrm{~mm}$ BP thickness and $0.30 \mathrm{~mm}$ minimum web thickness in current use, with state-of-the-art BP thicknesses of $\sim 1.1 \mathrm{~mm}$ and minimum web thicknesses of $\sim 0.15-0.2 \mathrm{~mm}$ ). Tensile and flexural strengths are lower than that for EG plates. Thermal conductivity is similar to that for stainless steel plates. In plane electrical conductivity is about an order of magnitude lower than that for EG plates, but through plane values are slightly higher.

Use of carbon and graphite coated metallic plates has been reported. Argonne National Lab has reported work (on composite fluoropolymer/graphite coatings on aluminum BPs (11). Coated panels show no corrosion; a single cell stack was tested with improved performance vs uncoated aluminum. Others have deposited carbon coatings on 304 SS (using chemical vapor deposition (CVD) or plasmaassisted (VD) and reported chemical stabilities comparable to Poco graphite and good corrosion resistance while providing higher electrical conductivity than uncoated material. (20) However, these studies were relatively short term.

An overview comparison of some of the technical properties of expanded graphite, bulk molded compound, and carbon-coated SS $316 \mathrm{~L}$ plates was presented (see following table). 


\begin{tabular}{|l|c|c|c|c|}
\hline Density $/ \mathrm{cm}^{3}$ & 1.7 & 1.89 & 8.0 & $\begin{array}{c}\text { Plate Weight } \\
<0.4 \mathrm{~kg} / \mathrm{kWnet}\end{array}$ \\
\hline $\begin{array}{l}\text { Thermal } \\
\text { Conductivity } \\
\mathrm{W} / \mathrm{mK}\end{array}$ & $\begin{array}{c}280(\mathrm{xy}) \\
5(\mathrm{z})\end{array}$ & 13 & 15 & $\mathrm{n} / \mathrm{a}$ \\
\hline $\begin{array}{l}\text { Electrical } \\
\text { Conductivity S/cm }\end{array}$ & $\begin{array}{c}1100(\mathrm{xy}) \\
20(\mathrm{z})\end{array}$ & $\begin{array}{c}70(\mathrm{xy}) \\
30(\mathrm{z})\end{array}$ & 13500 & $>100 \mathrm{~S} / \mathrm{cm}$ \\
\hline $\begin{array}{l}\text { Coefficient of } \\
\begin{array}{l}\text { Thermal Expansion } \\
\text { (CTE) }(\mu \mathrm{m})\end{array}\end{array}$ & $\begin{array}{c}1.0(\mathrm{x}, \mathrm{y}) \\
90(\mathrm{z})\end{array}$ & 30 & 16 & $\mathrm{n} / \mathrm{a}$ \\
\hline $\begin{array}{l}\text { Tensile/Flexural } \\
\text { Strength }(\mathrm{MPa})\end{array}$ & $40 / 60$ & $28 / 38$ & $\mathrm{NA} / 480$ & $\begin{array}{c}\text { Flex }>34 \\
\text { (carbon plate) }\end{array}$ \\
\hline \begin{tabular}{l} 
Corrosion $\mu \mathrm{A} / \mathrm{cm}^{2}$ \\
\hline
\end{tabular} & None & None & $<0.1$ & $<1$ \\
\hline
\end{tabular}

The recommended main focus area for expanded flexible graphite materials is high speed forming, sealing, curing, gluing and cutting operations to meet the automotive volume and cost targets. Roll embossing and adiabatic forming have been identified as candidate high speed forming routes to $100 k-500 k$ stacks/yr. Some encouraging R\&D/pilot scale scoping work has been performed on roller embossing and adiabatic forming. Roller embossing has been demonstrated at 9 meters/min by Terrella Energy. This line speed translates to 1 plate every 3 seconds. Very high density graphite parts have been demonstrated which reduce resin content, facilitating a sealing vs impregnation approach, with faster curing, enabling continuous operation. Adiabatic forming of a double-sided $160 \mathrm{~cm}^{2}$ test half-plate was demonstrated. The plate was formed in $<0.1 \mathrm{~s}$ using a high velocity impact unit, resulting in improved material flow and feature definition. This approach required less energy than for forming an identical metal part. Cost analyses that incorporate these new manufacturing scenarios are needed. For particulate graphite materials, a similar focus on high speed forming is suggested.

Additionally, thermal property improvements are needed for high current density operation.

\section{Corrosion Resistant Coating of Metal Bipolar Plates for PEM Fuel Cells (CH Wang, TreadStone)}

DOE's targets for BPs are shown in Table 1. The requirements are for corrosion resistance in PEM fuel cell operating conditions, low contact resistance, and low cost. Treadstone has evaluated two coating approaches to provide corrosion protection for metallic BPs, coatings with and without precious metals. Precious metal coatings offer exceptional stability and electrical conductivity, but the cost of the precious metal is high. Research has focused on reducing the precious metal coating thickness and reducing the surface coverage of precious metal on the substrate. For non-precious metal coatings, the materials cost is low, so the final cost is dominated by the processing cost. Challenges for these coatings are meeting the long-term durability, especially at transient conditions. Complicating matters is that the corrosion test condition at stack transient operation conditions is not defined by DOE, and each original equipment manufacturer (OEM) has its own testing protocols. During start-up/shutdown and local fuel starvation conditions potentials can reach those for oxygen evolution. (21) System designs have been implemented to minimize these transient conditions, but BPs should have reasonable tolerance to these conditions. Metal nitrides have been employed, but have stability issues at the high potentials that can be seen during transient operating conditions. Graphite coatings have been used, but thick coatings have been needed to reach the long term $(5,000 \mathrm{~h})$ operational durability targets. Conductive metal oxides appear to be a potential winning strategy. 
Treadstone's precious metal approach (DOTS technology) involves using a small amount of electrically conductive and corrosion resistant material (e.g., Au) to cover a small portion of the substrate surface in the form of isolated dots. Non-conductive (or poorly conducting) material is used to cover the rest of the substrate surface and separate the conductive dots. The dots electrically connect the plate base metal (stainless steel (SS) 316L) to the cell (GDL) to allow for current flow. In micro scale, the GDL only comes in contact with the metal plates at high points of the rough surface of the plates. On plates with gold dots on the surface, the dots can stand out of the rough surface of the SS plates and have more of a chance to be in contact with the GDL.

DOTS technology has been evaluated ex-situ and in PEM fuel cell stacks by Ford and is deemed ready for commercialization by Treadstone. The DOTS technology met all reported technical targets in the ex-situ testing by Ford, with corrosion currents of $\sim 0.1 \mu \mathrm{A} / \mathrm{cm}^{2}$ at the cathode and no active peak observed at the anode. Stack testing of the DOTS technology by Ford showed good durability for the duration of the test (2,000 hours) and decreasing interfacial contact resistance presumably as a result of the gold dots relaxing (and spreading) and providing additional contacting area between dots and GDL for current flow. The coating cost is low, but plate cost targets have not been met, due to the cost of the substrate, stamping and welding. Desired improvements to the DOTS technology include improved adhesion of the coating on the substrate and lower cost by reducing the thickness and surface coverage of the gold.

Treadstone's non-precious metal coating approach (TIOX technology) utilizes a semiconductive doped titanium oxide layer to provide corrosion resistance and reduce surface electrical contact resistance. Challenges with this approach include obtaining a low enough resistivity, since doped TiOX has low electrical conductivity, and obtaining reliable bonding of doped TiOX to the metal substrate. Treadstone addresses these challenges by depositing a thin layer of a $\mathrm{Ti}$ alloy ( $\mathrm{Ti}-\mathrm{Nb}$ or $\mathrm{Ti}-\mathrm{Ta}$ ) on the substrate and growing the corrosion-resistant doped TiOX semi-conductive surface layer from the alloy. The Ti alloy also provides a bonding layer that has excellent adhesion to the metal substrate and to the doped titanium oxide surface layer. Treadstone's TIOX technology has demonstrated superior corrosion resistance and meets DOE corrosion targets in both potentiostatic and potentiodynamic exsitu testing. Both $\mathrm{Ti}-\mathrm{Nb}$ and $\mathrm{Ti}-\mathrm{Ta}$ alloy coating show excellent stability even the extreme corrosive conditions, such as at $2 \mathrm{~V}_{\mathrm{NHE}}$ for 24 hours. Interfacial contact resistance for the $\mathrm{Ti}-\mathrm{Nb}$ is virtually unchanged on both anode and cathode sides after 1,100 hours in a single cell at constant current, remaining below $3 \mathrm{~m} \Omega \mathrm{cm}^{2}$ at 200 psi for both the anode and cathode plate. After 525 hours in a 10cell stack operating under dynamic testing conditions, the through plate resistance of the $\mathrm{Ti}-\mathrm{Nb}$ alloy coated plate increased at low compression pressures but remained nearly constant at 200 psi. Further development is focused on the manufacturing process to reduce cost and on investigation of the scientific mechanisms involved.

In general, further BP technology development for commercialization includes development of a roll to roll coating process for low cost manufacturing; development of a corrosion resistant coating capable of withstanding the physical impact and substrate deformation during plate stamping; development of plate joining (welding) technology compatible with the coating; high production yield in continuous production; and minimum capital investment for early market penetration.

\section{Modeling Performance and Stability of Bipolar Plates (Rajesh Ahluwalia, ANL)}

One of the functions of the BPs is to distribute reactants and product gases. An important part of this function is water management. Cost and performance considerations have driven stacks to run hotter and drier, especially under high power conditions, where water management should be less of an issue. With heat rejection constraints, fuel cell system cost for dealloyed PtNi/C catalyst stacks was found to be lowest at $2.5 \mathrm{~atm}$ stack inlet pressure at $95^{\circ} \mathrm{C}$ and $82 \% \mathrm{RH}$ cathode inlet, $103 \% \mathrm{RH}$ cathode 
outlet. Under these conditions, modeling shows only small amounts of liquid water in the flow channels. However, durability concerns suggest running at lower temperature $\left(65-80^{\circ} \mathrm{C}\right)$ when performance is not critical. This will incur a small efficiency penalty (1-2\%), but should increase lifetime. However, these cooler temperatures will lead to two-phase flow in the flow channels.

Kandlikar et al. have mapped two phase flow and pressure drop in micro channels and have identified 3 regimes of flow; slug flow, film flow, and mist flow. (22) Slug flow leads to blocked channels and is undesirable. Mench et al. have investigated the effects of coatings on liquid flow in channels, and demonstrated how hydrophilic coatings can help water removal through promoting the film flow regime. (23) Weber et al. have looked at the impact of GDLs by studying the drop detachment velocity. Lower drop detachment velocity correlates with better water removal, and can be a possible screening tool for new GDLs. (24)

To improve water management and flow characteristics, current SOA automotive BPs have moved to nearly straight flow channels. The impact has been that the plates have moved from having $75-90 \%$ active area with older serpentine plates to $40-60 \%$ active area with the near straight channels, due to the need for flow distributors with the straight channels.

The table below summarizes the BP technology against 2020 targets. The cost of BPs is one of the largest contributors to the overall cost of the fuel cell stack. Retention of electrical conductivity under fuel cell operating conditions is a key performance metric. A wide range of ex-situ corrosion tests (potentiodynamic, potentiostatic for both anodic and cathodic conditions) can help to understand material characteristics for real world conditions. In-situ stack level durability testing is imperative to verify a material's durability. Flow field design configuration is a key to the performance of fuel cells. Formability is an important attribute in the design space. SS $316 \mathrm{~L}$ has been studied as the baseline BP material. Corrosion currents were $<1 \mathrm{~mA} / \mathrm{cm}^{2}$, but interfacial contact resistance (ICR) was high, 1-2 orders of magnitude higher than the target of $5 \mathrm{~m} \Omega \mathrm{cm}^{2}$. This suggests coatings are needed to prevent formation of the passivating but resistive oxide film. Further investigation indicated that the ICR passivation film dissolved at all potentials from $0-1 \mathrm{~V}$, with the dissolution rate a function of the $\mathrm{pH}$. Potentiostatic release rates for the components were in the order $\mathrm{Fe}>\mathrm{Ni}>\mathrm{Mn}>\mathrm{Cr}$, with Fe release rates varying between $\sim 0.20-0.21 \mu \mathrm{g} \mathrm{cm}-2 \mathrm{~h}-1$ from 0 to $1.0 \mathrm{~V}$. Changes in SS 316L ICR with potential (0.2$1 \mathrm{~V})$ correlate well with modeled changes in oxide layer thickness (passive film). (25)

Several coatings have been investigated for SS 316L. Scientists at Jülich have investigated boron-doped diamond (BDD)/Nb coatings for service in poly benzimidizole (PBI) fuel cells. These exhibited high stability with no underlying passivation, however, the interfacial contact resistance (ICR) was above DOE targets at $65 \mathrm{~m} \Omega \mathrm{cm}^{2}$ at $150 \mathrm{~N} \mathrm{~cm}^{-2}$, and $30 \mathrm{~m} \Omega \mathrm{cm}^{2}$ at $300 \mathrm{~N} \mathrm{~cm}^{-2}$ (DOE Target: $<20 \mathrm{~m} \Omega \mathrm{cm}^{2}$ at $138 \mathrm{~N} \mathrm{~cm}^{-2}$ (200 psi)) (26). Ford has tested Au coatings, both as Au nanoclad ${ }^{\circledR}$ and Au dot coatings. They saw no significant increase in plate ASR during in-situ durability tests for either coating. Post analysis revealed no corrosion issues. ICP analysis did not detect any metal cations in the stack effluent water, indicating they were below the detection limit ( $\sim p p m)$. (27) Treadstone has recently investigated doped TiOX coatings for BPs. These films have shown low surface contact resistance ( $<5$ $\mathrm{m} \Omega \mathrm{cm} 2$ through plane resistance at $200 \mathrm{psi}$, and have shown good corrosion resistance at potentials up to 1.6V. (28) Sandvik has demonstrated graphite-like carbon (GLC) coatings on $304 \mathrm{~L}$ steel. GLC coated AISI 304L corrosion tests showed that currents are in the passive region between $0.6 \mathrm{~V}$ and -0.2 $V$, well below the target, $<1 \mathrm{~mA} / \mathrm{cm}^{2}$. Contact resistance was $3-6 \mathrm{~m} \Omega \mathrm{cm}^{2}$ at 14 bar, comparable to Au coatings (1.5-2 $\mathrm{m} \Omega \mathrm{cm}^{2}$ ). (29) Impact Coatings has developed a Ceramic MaxPhase ${ }^{\mathrm{TM}}$ coating. Ceramic MaxPhase coated BPPs showed stable performance for $5000 \mathrm{~h}$ in in-situ short stack tests at PowerCell with reformate fuel: $25 \mathrm{ppm} \mathrm{CO}, 500 \mathrm{~mA} / \mathrm{cm}^{2}, 70^{\circ} \mathrm{C}, 80 \% \mathrm{RH}$. 24 hour corrosion tests of this coating on SS 304 had corrosion currents below the DOE target of $1 \mu \mathrm{A} / \mathrm{cm}^{2}$. (30) 
With respect to modeling, the International Energy Agency (IEA) Annex 34 (Fuel Cells for Transportation) identified the following gaps and research needs for support of modeling efforts. Fluid mechanics of two-phase flow in state-of-the-art (SOA) metal BPs and flow fields needs additional effort, specifically, the effect of BP materials and coatings on pressure drops; liquid accumulation, distribution, and transport (especially in flow distributors); the effect of flow transients on robustness; and the role of the GDL in determining water distribution and removal.

Corrosion mechanisms can be elucidated by measuring specific material and coating behavior as a function of potential; by examining alternative substrate materials; by understanding corrosion currents in ex-situ potentiodynamic tests; by determining the effect of potential cycling on corrosion (metal dissolution) rates; by analyzing the effect of defects and imperfections in coatings; by designing protocols for developing BP durability models; and by correlating in-situ and ex-situ corrosion rates. Transport of BP corrosion products (metal ions) can be better understood by measuring the effect of cations on electrode, membrane, and MEA performance.

Interfacial contact resistance can be characterized by parametric measurement as a function of contact pressure, potential, and exposure.

\begin{tabular}{|c|c|c|c|c|c|c|c|c|c|}
\hline Characteristic & Units & 2020 Targets & \begin{tabular}{|l|} 
ANL, LANL, \\
ORNL, NREL \\
\end{tabular} & UTRC & Ford & $\begin{array}{c}\text { Ford, } \\
\text { Treadstone }\end{array}$ & Treadstone & $\begin{array}{l}\text { Impact } \\
\text { Coatings }\end{array}$ & Sandvik \\
\hline $\begin{array}{l}\text { Plate or Coating } \\
\text { Material }\end{array}$ & & & SS-316L & Graphite & Au-Nanoclad & Au-Dots & $\begin{array}{l}\text { Doped } \\
\text { Titania }\end{array}$ & $\begin{array}{c}\text { Ceramic } \\
\text { MaxPhase }\end{array}$ & PVD-GLC \\
\hline Coating & & & Uncoated & Uncoated & Pre-Coated & Post-Coated & & & Pre-Coated \\
\hline Plate Cost ${ }^{b}$ & $\$ / \mathrm{kW}$ & 3 & & & & & & & \\
\hline Plate Weight & $\mathrm{kg} / \mathrm{kW}$ & 0.4 & & & & $<0.3$ & & & \\
\hline $\begin{array}{l}\text { Plate } \mathrm{H}_{2} \text { permeation } \\
\text { coefficient }^{c}\end{array}$ & $\begin{array}{c}\text { Std } \mathrm{cm}^{3} /\left(\mathrm{s} \mathrm{cm}^{2} \mathrm{~Pa}\right) \\
@ 80^{\circ} \mathrm{C}, 3 \mathrm{~atm} \\
100 \% \mathrm{RH}\end{array}$ & $<1.3 \times 10^{-14 d}$ & & & & & & & \\
\hline Corrosion, anode $\mathrm{e}^{\mathrm{e}}$ & $\mu \mathrm{A} / \mathrm{cm}^{2}$ & $<1$ & 0.3 & & No active peak & No active peak & No active peak & & $<1$ \\
\hline Corrosion, cathode $^{\dagger}$ & $\mu \mathrm{A} / \mathrm{cm}^{2}$ & $<1$ & 0.4 & & $\sim 1.0$ & $\sim 0.1$ & $<0.02$ & $\sim 0.075$ & \\
\hline Electrical conductivity & $\mathrm{S} / \mathrm{cm}$ & $>100$ & & & & 3400 & & & \\
\hline Areal specific resistance ${ }^{g}$ & $\mathrm{~m} \Omega-\mathrm{cm}^{2}$ & 10 & 420 & $\sim 15$ & $5-6$ & $8.4-6.4$ & $6-8$ & $\sim 11$ & $3-6$ \\
\hline Flexural strength $^{\mathrm{h}}$ & $\mathrm{MPa}$ & $>25$ & & & & & & & \\
\hline Forming elongation & $\%$ & 40 & & & & $53-64$ & & & \\
\hline
\end{tabular}




\section{Bipolar Plate Durability Testing (Rod Borup, LANL)}

The DOE BP targets with associated protocols have been shown previously in Table 1. For durability, the main concerns are the corrosion behavior and changes in the Areal Specific Resistance (including contact resistance). Completely accurate corrosion behavior can only be obtained by long-term commercial-scale testing at real conditions, which is obviously impractical. Therefore, a battery of exsitu and small in-situ tests have been developed to assess corrosion behavior. DOE protocols call for a potentiodynamic test at $0.1 \mathrm{mV} / \mathrm{s}$ from -0.4 to $+0.6 \mathrm{~V}(\mathrm{Ag} / \mathrm{AgCl})$ at $80^{\circ} \mathrm{C}$ for the anode at a $\mathrm{pH}$ of 3 with $0.1 \mathrm{ppm} \mathrm{HF}$ de-aerated with an Ar purge. For the cathode, the test is potentiostatic at $+0.6 \mathrm{~V}(\mathrm{Ag} / \mathrm{AgCl})$ $80^{\circ} \mathrm{C}$ for $\geq 24 \mathrm{~h}$ at a pH of 3 with $0.1 \mathrm{ppm} \mathrm{HF}$ in an aerated solution. However, in reported testing, procedures and conditions for measuring corrosion properties have varied by research entity. For example, the potential used in the potentiostatic tests has varied from $0.6 \mathrm{~V}(\mathrm{Ag} / \mathrm{AgCl})$ to $1.6 \mathrm{~V}(\mathrm{NHE})$, temperature has varied (tests at $25^{\circ} \mathrm{C}, 70^{\circ} \mathrm{C}$, and $80^{\circ} \mathrm{C}$ ), sulfuric acid concentration has varied $(1 \mathrm{M}, \mathrm{pH}$ $1-3$, and $\mathrm{pH} 3$ ), as has the HF concentration ( $2 \mathrm{ppm}, 0.1 \mathrm{ppm}$, ). Anodic corrosion behavior of several metal plate materials was investigated (SS 316L, Hastelloy, NiCr) as a function of temperature and fluoride ion content. Temperature increases (from 40 to $80^{\circ} \mathrm{C}$ ) increased the corrosion rate and decreased the free corrosion potential (OCV). Increasing the fluoride ion concentration (from 0 to 100 $\mathrm{ppm}$ ) had a smaller effect. Correlation of the various ex situ corrosion tests to in situ life performance is needed.

New protocols continue to be developed. To speed up characterization of the dissolution behavior and come closer to the situation in a cell, LANL has developed potentiometric measurements that attempt to mirror the environment seen by the BP in a PEM cell. The experimental setup places the plate material between two Pt/C electrodes (ELAT $0.5 \mathrm{mg} \mathrm{Pt} / \mathrm{cm} 2,20 \% \mathrm{Pt}$ on C). The ionomer membrane is replaced with solutions of $0.001 \mathrm{~N} \mathrm{H}_{2} \mathrm{SO}_{4}$ containing $2 \mathrm{ppm} \mathrm{F-}$. Hydrogen and air are fed to the anode and cathode faces, and the electrical potential between components is recorded to monitor oxide growth. (31) A procedure for measuring contact resistance between a metal plate and GDL materials has been published (32). The experimental set up recommends placing the plate material between two carbon paper GDL's in contact with Au coated plates and applying a compaction force. The target is for a face value of 0.01 to $0.02 \mathrm{ohm}-\mathrm{mc} 2$ at a compaction force of $150 \mathrm{~N} / \mathrm{cm} 2$

LANL has also looked at ageing of metal BPs in simulated drive cycle testing, including wet and dry, high power, low power, and idle conditions. From visual inspection, metal corrosion was found to be more severe on the anode plate than on the cathode plate; the primary areas where corrosion has been noted are areas where significant amounts of liquid water are present. Previous work by LANL with identical flowfield geometry under similar operating conditions $(100 \% \mathrm{RH}, \mathrm{H} 2 /$ Air co-flow with outlets at hardware bottom) showed liquid water in the hardware flowfield in positions remarkably similar to the positions where the corrosion was observed in this test. Nitrided Hastelloy plates were tested in-situ to evaluate the rate of metal contamination of the ionomer/membrane and the rate of increase in contact resistance. After $300 \mathrm{~h}$ of the drive cycle, contact resistance increased at low contact force. At high contact force (>50 lb-in) the contact resistance decreased. Membrane resistance increases when metal cations migrate into the MEA/Membrane. With these corrosion resistant nitride Hastelloy metal plates, LANL observed no increase in MEA metal cations after the drive cycle testing. In fact, the MEA showed lower metal cation content after the drive cycle testing than before. The in-situ testing to date has not included start-up/shutdown cycles or free corrosion (extended time at off conditions). This may or may not matter depending on liquid water removal.

The research needs summarized by Ballard in 2014 (33) are generally still valid today. Correlations between lab conditions and ex-situ tests and real-life in-situ life performance are needed. Work on life 
prediction strategy of coatings needs to include more aspects of corrosion such as potential holds and potential cycles, crevice corrosion, the impact of calendar life (prolonged off condition), as well as AST development to support life prediction models. Potential hold studies should be used to define the limits of the candidate materials with emphasis on key substrates as a baseline and to map corrosion as a function of $\mathrm{pH}$, temperature, and potential. The impact of joining on base materials and surface coatings as it relates to corrosion stability needs to be considered. Interactions between plate corrosion and membrane degradation need to be understood to identify coupling effects that accelerate transfer leaks and corrosion. Resolution of the aforementioned issues should be guided by an assessment of existing models on plate corrosion including corrosion mechanisms, transport of metal species in fuel cells, and the rate of accumulation of metal species in MEA materials. A gap analysis/validation and public dissemination of DOE models should be included. Finally, the long-term compatibility of BP materials with hydrogen atmosphere over a range of conditions must be established.

\section{Forming and Manufacturing Issues in Automotive Bipolar Plate Production (Simon Farrington, AFCC)}

The interaction of the plate material and the forming process determines what geometries are achievable in a BP. For water management narrow channels with tight curvature at the corners of narrow upstanding landings are desirable. Stretch-formed flow fields cannot achieve the target geometries (based on loss optimization). This leads to requirements for increased pressures and pressure drops for effective water management. However, molded or embossed flowfields (plastic forming only) can achieve the desired geometries, providing stable performance under wet conditions and may enable alternative flow field architectures that provide process cost savings (e.g. robust to cavity-cavity variations, input material property variations).

The performance of three BP material sets are assessed: roller embossed expanded graphite/resin composite (EGR), compression molded particulate graphite/resin composite (PGR), and stretchformed coated stainless steel foil BPs (CSS). Manufacturing process costs and technology gaps are enumerated. All of the concepts must address flow uniformity and interfacial contact resistance based on flow field design.

The expanded graphite/resin composite (EGR) plate exhibits sufficient mechanical properties and feature definition to meet the design requirements (radii, depth, draft, and thickness), but refined material models are needed to optimize the forming of the finished composite for specific applications. Contact resistance is the largest component of electrical loss for EGR plates, as it is for all plate options. Post-processing has not been required to activate this material surface. The thermal conductivity is high (approx. $300 \mathrm{~W} / \mathrm{mK}$ ), due to the continuously conductive graphite phase. The requirement for low contact angles requires development of manufacturing and/or material/design solutions. With roller embossing, EGR plates can achieve densities of $>1.8 \mathrm{~g} / \mathrm{cm}^{3}$ with low levels of elastic recovery. The low levels of resin required $(<5 \%)$ limit shrinkage on cure to very low levels.

Internal AFCC estimates place the process cost of EGR plates at $\$ 1.63$ per BP assembly (excluding profit margins), with estimated capital cost of $\$ 5.6 \mathrm{M}$ at 20,000 vehicles/year production volume. The cost was most sensitive to materials cost, followed by sensitivity to the number of tool cavities per cycle and then the forming cycle time. Material cost reduction is possible by further refinement of the roller embossing pre-processing steps and potentially by use of low cost fillers. The cost estimate has a low sensitivity to the cycle time, due to the low capital cost and low footprint requirements.

Sensitivity to parallel processing could be exploited by utilizing side-by-side multi-cavity tooling for further cost reduction. Continuous impregnation and cure processes to replace batch steps are 
considered feasible. The Process steps are proven, however immature. The Supply chain is incomplete and the development of pilot scale capabilities within the supply base is required to realize low costs.

EGR R\&D needs include further roller embossing process development to scale-up the sufficient precision and accuracy that has been achieved to continuous production. Additional savings and forming enhancements may be possible with use of low cost fillers and manufacturing and/or material/design solutions are needed for low contact angle surfaces. Process development to integrate impregnation and curing developments into a fully continuous process is also needed.

The compression molded particulate graphite/resin composite (PGR) plate feature definition is sufficient to meet design requirements (radii, depth, draft, thickness). Mechanical properties are sufficient but need to remain high in the context of possible applications that may require reformulation. Thermal conductivity is low (35-45 W/ mK), for high current density applications because premixing resin and graphite disrupts the continuously conductive material phase. Improvements are needed, and may be possible by addition of highly conductive fillers. Contact resistance is the largest component of electrical loss. Low cost post-processing is now close to optimal by at least two (un-named) methods. The surface energy requirement for low contact angles still requires development of manufacturing and/or material/design solutions. Resin cure speeds (higher cure speed means less time in the press, reducing cost and the number of processing lines) have improved and need continued development. Highly conductive fillers may facilitate cure time reduction.

Initial cost studies place the baseline cost for PGR plates at $\$ 2.36$ per BP assembly (excluding profit margins), with estimated capital cost of $\$ 27 \mathrm{M}$ at 20,000 vehicles/year production volume. $A$ sensitivity analysis indicated the cost was most sensitive to molding cycle time, followed by capital costs, and then materials cost. The high sensitivity to cycle time is due to the high capital requirements. Pre-impregnation and pre-forming processes require further development or outright elimination for further cost reductions. The cure-in-press process imposes a fundamental cycle time limitation. Resin cure speeds (press closed time) have improved on this limitation but need additional improvement. Highly conductive fillers may facilitate cure time reduction. The current supply chain is healthy, and supplier choice exists, allowing quality/cost trade-offs to be made.

Development needs for compression molded, particulate graphite composites include improved material thermal conductivity (for cure time and operational benefits), press cycle time improvements (which may come from above), and manufacturing and/or material/design solutions to provide surfaces with low contact angles.

Stretch-formed coated stainless steel foil BPs cannot meet geometry targets based on optimized insitu performance loss breakdown analysis because of substrate properties and forming limitations. Thermal conductivity is low $(16 \mathrm{~W} / \mathrm{mK})$, presenting a risk for high current density applications. The low thermal conductivity of the stainless steel limits part performance at high heat fluxes and at extremes of operation when conductive web cross-sections are small. Contact resistance with the GDL is low, competitive, and dependent on coating properties. The requirement for low contact angle requires coating surface engineering solutions. Trade-offs with contact interface performance are anticipated. Low overall thickness and feature dependency present significant fluid handling challenges for the cell designer, particularly at high current densities.

Cost estimates place the baseline CSS plate cost at \$3.17/BP assembly (excluding profit margins), with estimated capital cost of $\$ 43 \mathrm{M}$ at 20,000 vehicles/year production volume. The highest risk is substrate material cost, followed by the coating cost, where there is a lack of viable options for both. 
More development in coatings is needed. Sensitivity analysis also indicates the cost is sensitive to the welding speed and the capital outlay. Laser welding is not demonstrated at high throughput in similarly complex parts. Significant design trade-offs and challenges exist between welding and part performance. Cleaning process cost has a low impact on plate cost.

Development needs for metallic plates include low cost substrate materials that can be consistently formed to target profiles (based on stack performance and operational stability) and durable substrates or very low cost coatings. Alternative flowfield designs to reduce electrical losses (wide channels, landings) and improve stability (dimensional conformance) could also enable this technology. Improvements are needed in low cost, high speed welding or alternative high speed joining methods. Material property improvements and/or increased flow domain depths (part thickness) are needed to tackle thermal distribution issues. Increased part thickness will also help to maintain reasonable flow domain depths for low flow resistances, with respect to system efficiency. Lower contact angle surfaces are needed for wet-flow stability (this may be relieved by alternative flowfield designs, depending on the concept).

\section{Approaches to Provide a Metallic Bipolar Plate Module to the Industry (Raimund Stroebel, Dana Corp)}

Dana has been active in metallic BPs for some time, stamping their first metallic plates in 2001, providing coated plates in 2005, and providing plates with their beaded seal in 2007. Dana launched production of standardized plates in 2012 , and launched production using progressive die stamping in 2014. Dana has concluded that industrialization of fuel cells requires design to both cost and manufacturing.

Recent trends in flow fields for BPs have led to a reduction in the ratio of active area to passive area. For automotive plates, the ratio of active area to passive area falls between 0.4 and 0.65 , with most around 0.5 . Increasing the fraction of active area could increase power density and decrease cost and weight.

For moderate vehicle production rates of 30,000 vehicles per year, approximately 10 million MEAs and 20 million plates are needed. These high volumes demand that processes be high-throughput. Dana utilizes a high speed stamping process with progressive dies for cutting and stamping that provides microstructures of $\leq 100 \mu \mathrm{m}$. This is followed by joining, then coating, followed by the sealing process.

Sealing is a critical issue both for fuel cell performance and in fuel cell manufacturing. Using a traditional sealing approach of an MEA with an injection-molded gasket, Dana estimates a throughput of 1 plate/45 sec. At that rate, 21 injection-molding cells are required for a production rate of 30,000 vehicles per year (10,000,000 MEAs). Higher throughput is needed. Dana has developed an integrated metallic bead seal that can increase throughput and reduce machine costs. The seal is an integrated part of the BP module, produced simultaneously with the BP. This technique produces a gas tight seal, with only minor gas permeation due to the low permeability of the metal. Dana's design also allows for flexibility and individual adjustment to the plate and port geometry and soft goods, and a simplification of the assembly process. Using their bead seal, Dana estimates that the $10,000,000$ MEAs per year for 30,000 vehicles can be processed on 1 machine (versus the 21 needed for the traditional approach) at a line speed of $12 \mathrm{~m} / \mathrm{min}$. By utilizing integrated components (metallic BP with integrated seal and low cost coating and integrated laminated MEA), stack assembly can be simplified. To aid in the assembly, the plates are designed for ideal pick-and-place structures. 
Dana's BPs and bead seals have been demonstrated in the ZSW Foundation's AutoStack CORE project to build and test a 100-kW automotive fuel cell stack. BPs for the second generation stack have increased the active/passive area for the plates from $46 \%$ to $52 \%$ and reduced the cell pitch from 1.2 to $1.0 \mathrm{~mm}$, which along with other improvements led to an increase in stack power density from 2.8 to $3.5 \mathrm{~kW} / \mathrm{L}$

\section{BREAKOUT SESSION (Materials and Coatings)}

Four parallel breakout sessions were convened to identify R\&D needs for Materials and Coatings. All four teams addressed materials and coatings for both metal and composite BPs. The following questions served as catalysts for the discussion:

How can materials and coating costs be reduced and performance/durability be improved? What base materials provide the most potential to meet BP cost, durability and performance targets for automotive applications?

What are the issues limiting the use of metallic BPs and are there grade or composition requirements (e.g. limitations on Fe or Ni content)?

What are the main issues limiting coating technologies for metal-based BPs?

For non-metallic (carbon) plates, what are the issues limiting their use in automotive fuel cell applications?

What R\&D is needed to address these issues and what are the priorities?

Are there improvements in other cell or stack components that could alleviate plate requirements?

Groups were almost evenly divided on their opinions of the relative importance of work on metal and carbon/carbon composite plates. In the area of metal plates, the main issues identified as limiting plates were forming limitations, cost, and corrosion concerns. Cost and corrosion are correlated, as the more corrosion resistant materials are higher cost. Overall, participants considered work on Al and Al alloys a higher priority than work on stainless steels (including low Ni steels), which was higher priority than work on Ti alloys. Al and Al alloys were discussed as being cheaper, easier to form, and lighter. However, concerns about Al corrosion were expressed and there was a portion of the attendees who had the opinion that Al would require a perfect or near perfect coating, which would be very difficult to achieve. Lower grade stainless steels, with low Ni content were discussed, but forming of these materials was considered more difficult. Corrosion of these materials was also a concern. Titanium has good corrosion properties, but was considered too expensive. However, some commented on the possibility of powder processing for titanium substantially reducing costs. Forming tolerances and the tradeoffs with processing and joining issues (welding) when going to thinner foils were also mentioned as areas where $R \& D$ is needed. There was some interest in investigating other alloys and materials, with an emphasis on lowering cost (compared to SS 316L) while providing some corrosion protection.

The main issues identified as limiting coatings were processing, cost, and coating quality. The majority of current coatings need to be applied post-forming. If the coating can be applied pre-forming it is believed it will lead to lower costs due to easier handling (roll-to-roll versus individual parts). The cost of the coating material (in the case of precious metal coatings) or the cost of the coating application is too high. The presence of defects and imperfections in the coatings can lead to unacceptable leaching of the substrate material. The adequacy of the coating for corrosion protection depends on the base material. Current coatings can provide sufficient corrosion protection for SS 316L, but the cost of the base material is too high. For materials such as Al, the coating needs to be perfect, and the present technology is not adequate. High priority R\&D areas identified for coatings include coatings that can 
be formed (applied pre-forming), coating-manufacturing interactions, and more detailed corrosion studies, including following corrosion at specific locations such as coating defects and imperfections.

For carbon materials, limiting issues that were identified include sealing the plate and potential permeability to $\mathrm{H}_{2}$ or air, flexural strength of the plates, quality control, and high volume manufacturing capacity/throughput. Attendees thought that carbon plates can be made with the appropriate cell pitch to meet power density targets, and Simon Farrington presented data indicating cell pitch and web thickness could be comparable to metal plates. While he also presented work showing roll-to-roll processes for expanded graphite resin plates, other attendees still had some question about whether carbon/carbon composite plates can be made at acceptable throughputs. R\&D on composites and $C$ resins and sealing were seen as the highest priority item to address, with work on high-speed manufacturing seen as the next most important aspect for carbon/carbon composite plates. There was concern about the supply chain and quality control with carbon/carbon composite plates. Recyclability was also mentioned as an area of concern.

For both metal and carbon plates, improved MEA performance to increase power density was thought to be important for reducing cost/kW of the BPs. There was also some discussion that the plates (and other components) are over-engineered in some aspects, and that the design specifications can be relaxed and still meet the overall system targets.

\section{BREAKOUT SESSION (Manufacturing)}

Two parallel Breakout Sessions were convened to identify R\&D needs for manufacturing. Both teams addressed metal and composite BPs. The following questions served as catalysts for the discussion:

Are current forming, methods adequate (quality, cycle time, cost)?

Are current joining/sealing methods adequate (quality, cycle time, cost)?

Are current coating methods adequate (quality, cycle time, cost)?

Can multiple steps be combined into a single step (e.g., stamping and joining; stamping and coating during forming)?

How can manufacturing costs be reduced?

Priorities were not the same for the two breakout manufacturing groups but two overarching themes were evident, cycle times need to be reduced and quality needs to be improved, both of which have implications for cost. Although millions of BPs have been manufactured and placed in service in fuel cell vehicles (FCVs), buses, material handling equipment (MHE), and stationary applications, cost is still an issue, driven by material and processing costs. High carbon processing costs are primarily a result of long composite curing times. Materials development was the main approach suggested to decrease curing times. Other curing methods such as e-beam, ultra-violet (UV) or photonic curing were also suggested as possible methods to decrease cure times. Roll embossing was one method suggested to improve throughput for forming of carbon composite plates. Metal BPP assembly processing costs are driven by forming and joining speeds and coating application. Brian James presented an estimate that stamping costs alone account for $\$ 3.40 / \mathrm{kWnet}$ and that his baseline progressive stamping case would require 110 simultaneous process lines to meet the BP needs for 500,000 vehicle/year production rate. This number of production lines is not reasonable, and would lead to serious quality control concerns. Options discussed to improve throughput were increasing the number of parts per press, roll embossing, hydroforming, adiabatic stamping and explosive forming. The quality and tolerances of the forming processes are key factors to investigate. Potential re-rolling after stamping/forming was also suggested as a possible route to increase throughput by minimizing part picking and placing time. Welding metal plates is time consuming and complicated. High-speed laser welding and nontraditional approaches such as welding the whole plate at once were identified as potential solutions 
to increase throughput. Other potential solutions identified included diffusion bonding and gluing rather than welding. However, it was noted that adhesive joints have had higher failure rates than welds. The need for high-volume manufacturing studies was also recognized for both carbon and metal plates

As discussed in the AFCC presentation, traditional stamping limits the geometry of stamped metal flow fields to less than ideal geometries. Adiabatic and explosive forming are potential approaches to enable metal plates to achieve the desired geometries. Metal plate properties (forming limits) and their behavior during alternative forming such as hydroforming, adiabatic forming, or explosive forming should be evaluated. Forming die tool life and how wear affects tolerances was identified as an issue. Other methods to impart flow fields, such as 3D printing and embossing were identified as alternatives, but are at low TRL levels. One of the breakout groups expressed doubts that additive manufacturing could have sufficient throughput to be useful for this application. It was also suggested that alternative flow field designs could relax the requirements for stamping (with the extreme of a flat plate with a foam flow field).

The area of coatings was a medium priority for both groups. Current coating cycle times are considered to be too high. Several coatings require vacuum processing, which adds cost. For PVD coatings, research should target reducing materials cost and waste. Research to develop coatings that can be applied prior to stamping was also identified as a priority. Different deposition techniques such as ink-spray coating or techniques that apply the coating or surface treatment in the stamping or embossing steps could potentially reduce cycle times and costs for coating deposition. Quality control of coatings is also an area of concern. The repeatability of the coating process in high volume manufacturing needs to be demonstrated and in-line inspection of coatings to verify uniformity and repeatability would be beneficial. Studies determining how manufacturing processes affect quality should be a part of these studies.

\section{BREAKOUT SESSION (Modeling/Testing)}

Two parallel Breakout Sessions were convened to identify R\&D needs for modeling and testing different aspects of BPP technology. The following questions served as catalysts for the discussion:

Can a fundamental understanding of technical limitations of various BP materials, including carbon composite and metallic plates be gained by modeling?

Are models for fluid flow and water transport adequate?

Where else can modeling address BP needs?

Are existing test protocols sufficient and appropriate for all plate types, or will new tests be needed for new materials/coatings?

Are technical targets and parameters comprehensive? What needs to be added, changed, improved or deleted?

Are ex-situ tests instructive?

Do we have appropriate accelerated tests for BP ageing ex-situ? In-situ?

The breakout groups agreed that modeling can help us understand forming limitations. Models for forming large parts, such as fenders, currently exist but we do not have models to predict forming of BP flow-fields. Models are needed that can predict/calculate flatness, bend radii, and residual stresses for various stamping/forming conditions and various materials. The breakout groups also agreed that current 2-phase flow models are inadequate for describing water and water vapor transport.

Development of 2-phase flow models with a focus on the effects of flow fields on system behavior including start-up and transients is desirable. Modeling to predict how dimensional tolerances and variability affect performance and durability was also suggested. However, flow field design is 
considered a competitive research area by the OEMs, so the OEMs do not think modeling directed toward developing new or improved flow field designs is an appropriate area for DOE. Cost modeling was also seen as worth pursuing. A cost model for composite plates was suggested as a high priority. An impartial study comparing cost for the current SOA for carbon and metal plates is needed. A predictive corrosion model was also a high priority need. Current corrosion models lack predictive capability. In particular, models that can provide transfer functions or correlations between the shortterm durability tests and real world long-term fuel cell operation are needed. Models are also needed to understand plate-GDL interfacial contact resistances for different contact pressures, potentials, exposure times, and materials.

For the area of testing, the two highest priorities were flow distribution testing and materials-specific targets. The flow testing involves reactant distribution, residence time, pressure drop, channel dimensional tolerances, and the effect of GDL intrusion into flow channels. Improved physical characterization of water in-situ is needed to inform model development with reliable results. Materials-specific targets are especially relevant to differences between carbon and metal plates and to corrosion and degradation products' effect on the MEA. For example, corrosion of titanium within present specific targets may result in (benign) Ti in the membrane whereas corrosion of SS puts (very deleterious) Fe in the membrane at the same corrosion current. Likewise, leachates from carbon plates depend on the raw materials (e.g., resin composition). Development of targets for scratch resistance, coating adhesion, plate-to-plate adhesion, and surface energy stability was suggested. Improved understanding of the relationship between in-situ and ex-situ corrosion would support development of such targets.

The remaining items all had essentially the same priority. Accelerated Stress Tests (ASTs) and ex-situ corrosion tests need to be correlated to in-service lifetimes. Additional ASTs and test protocols are needed for specific stressors during cell/stack operation such as high voltage. Anode corrosion is not sufficiently understood and development of the transfer function from a "2-hour anodic polarization to long-term fuel cell operation" would support a predictive corrosion model. Experimental characterization of the mechanical properties of new materials at the appropriate length scale would benefit modeling of manufacturing and in-cell behavior.

\section{Conclusions}

Current bipolar plate technologies do not meet the DOE cost targets. Metal plates and carbon/carbon composite plates each have areas where they have advantages and where they have development issues. Metal plates have allowed finer cell pitch and more rapid processing, but have suffered from high materials costs, low formability, and/or corrosion products that negatively impact cell performance. The cost of the current plate material, SS 316L, is estimated to be $\$ 3.5 / \mathrm{kW}_{\text {net, }}$, higher than the DOE target of $\$ 3 / \mathrm{kW}$ for a finished plate. R\&D priorities for metallic BP materials are improving the forming limit of the substrate materials (thin metallic foil) and developing robust coating materials that allow the use of less expensive substrates and enable a pre-forming deposition process (coat before the forming). Deposition processes that mitigate coating defects (such as cracks or delamination) during the stamping process, provide self-protection from corrosion/degradation at coating defect areas, provide chemical stability (particularly mitigate leaching of metal ions which are harmful for other components, e.g. the membrane), eliminate PGMs or precious metal for lower cost, and are amendable to a high-throughput manufacturing process are also of interest. Carbon composite plates offer lower materials cost than SS plates, good corrosion resistance, potential for lower weight, and higher formability. However, plate strength is lower and processing times have been long, leading to high processing costs. For carbon composite plates, high throughput production 
processes and materials that promote high throughput are needed. Higher strength materials and materials that improve thermal conductivity would be beneficial. Testing procedures and targets that are specific to the material and that are closer to real-world conditions are needed to further advance the field. Modeling could provide additional insight into formability and performance. Improvements are needed in forming models, two-phase flow models, and durability models.

References

1) B. James https://www.hydrogen.energy.gov/pdfs/review16/fc018_james_2016_o.pdf

2) https://en.wikipedia.org/wiki/Ford_EcoBoost_engine\#Specifications_2 2

3) http://wardsauto.com/2015/2015-winner-ford-10l-ecoboost-dohc-di-i-3

4) https://energy.gov/sites/prod/files/2016/06/f32/ace000_singh_2016_o_web.pdf

5) https://energy.gov/sites/prod/files/2017/05/f34/fcto_myrdd_fuel_cells.pdf

6) M. Onischak, L. G. Marianowski, S. Thielman, and Q. Fan, Development of a $\$ 10 / \mathrm{kW}$ Bipolar Separator Plate, P. 110, https://energy.gov/sites/prod/files/2014/03/f10/10.pdf

7) M. Bortner, Economical High Performance Thermoplastic Composite Bipolar Plates, https://www.hydrogen.energy.gov/pdfs/progress06/v_d_5_bortner.pdf

8) O. L. AdrianowyczNext Generation Bipolar Plates for Automotive PEM Fuel Cells, https://www.hydrogen.energy.gov/pdfs/progress09/v_g_2_adrianowycz.pdf

9) A.S. Woodman, E.B. Anderson, K.D. Jayne, and M.C. Kimble, Development of Corrosion Resistant Coatings for Fuel Cell Bipolar Plates, AESF SUR/FIN ‘99 Proceedings, 6/21-24, 1999.

10) M.P. Brady, T.J. Toops, and P. F. Tortorelli, Nitrided Metallic Bipolar Plates, https://www.hydrogen.energy.gov/pdfs/review10/fc022_tortorelli_2010_o_web.pdf

11) J. Mawdsley, S. Niyogi, X. Wang, J. Carter, Metallic Bipolar Plates with Composite Coatings, https://www.hydrogen.energy.gov/pdfs/review11/fc024_mawdsley_2011_o.pdf

12) C. H. Wang, Low-Cost PEM Fuel Cell Metal Bipolar Plates https://www.hydrogen.energy.gov/pdfs/progress11/v_h_1_wang_2011.pdf.

13) C. H. Wang, Novel Structured Metal Bipolar Plates for Low Cost Manufacturing https://www.hydrogen.energy.gov/pdfs/progress16/v d 2 wang 2016.pdf

14) US Patent 8,053,141 B2 (2011), DE Patent Application 10235598 A1 (2002),DE Patent Grant 10235598 B4 (2005).

15) H. Tang, et. al., J of Power Source 158 (2006) 1306-1312

16) PratitiMandal, et. al., 3D Imaging of Fuel Cell Electrode Structure Degraded under Cell Reversal Conditions Using Nanoscale X-ray Computed Tomography, 228th ECS meeting in Phoenix, AZ

17) S. Knights et al., U.S. Patent, 6,936,370 B1 (2005)

18) S. Hirano, et al., Multi-Layer Thin Film Coating on BPs for PEMFC, PRiME 2016 (ECS), Oct 2016

19) S. Hirano et al., US Patent 8,232,026B2 (2012).

20) Karimi et al., Advances in Materials Science and Engineering Volume 2012 (2012), Article ID 828070

21) J. P. Meyers, R. M. Darling, JECS., 153, A1432-A1442 (2006)

22) Z. Lu, S.G. Kandlikar, et al, "Water Management Studies in PEM Fuel Cells, Part II: Ex Situ Pressure Drop and Two-Phase Flow Patterns in Gas Channels," International Journal of Hydrogen Energy, 34(2009), 3445-3456.

23) A. Turhan, S. Kim, M. Hatzell, M. Mench, Electrochimica Acta, 55(8),2734-2745,(2010).

24) A. D. Santamaria, P. K. Das, J. C. MacDonald, A. Z. Weber, J. Electrochem. Soc., 161 (12), F1184F1193 (2014).

25) R. K. Ahluwalia, Performance Requirements of BPs for Automotive Fuel Cells, , ANL IEA Annex 34 Meeting on Metal BPs for Automotive PEM Fuel Cells (Nov. 2015 ).

26) Vitali Weißbecker, Effect of Potential and Temperature on Electrochemical Corrosion of Metallic BPs for HT-PEFCs, FZ Jülich, IEA Annex 34 Meeting on Metal BPs for Automotive PEM Fuel Cells (Nov. 2015 ) 
27) Shinichi Hirano, R\&D for Automotive Fuel Cell Systems - Bipolar Platess, Ford Motor Company, IEA Annex 34 Meeting on Metal BPs for Automotive PEM Fuel Cells (Nov. 2015)

28) Conghua Wang, Metal Bipolar Plate Coating for PEM Fuel Cells, TreadStone Technologies, IEA Annex 34 Meeting on Metal Bipolar Plates for Automotive PEM Fuel Cells (Nov. 2015 )

29) Hanna Bramfeldt, Sandvik Surface Technology - Commercializing Bipolar Plate production, IEA Annex 34 Meeting on Metal BPs for Automotive PEM Fuel Cells (Nov. 2015)

30) Henrik Ljungcrantz, Ceramic MaxPhase ${ }^{\mathrm{TM}}$ - a highly conductive, low cost, and corrosion resistant coating on metal Bipolar Plates for PEM fuel cell, Impact Coatings, IEA Annex 34 Meeting on Metal Bipolar Plates for Automotive PEM Fuel Cells (Nov. 2015 )

31) K. Wiesbrod, U.S. Patent \# 6,454,922(2002)

32) Dionissios D. Papadias, Rajesh K. Ahluwalia, Jeffery K. Thomson, Harry M. Meyer III , Michael P. Brady, Heli Wang, John A. Turner, Rangachary Mukundan, Rod Borup, Degradation of SS 316L Bipolar Platess in simulated fuel cell environment: Corrosion rate, barrier film formation kinetics and contact resistance, Journal of Power Sources, Volume 273, 2015, 1237 - 1249

33) Shanna Knights, DOE Durability Working Group Meeting, Argonne National Laboratory, Dec. 11, 2014 


\section{Appendix A List of Attendees}

\begin{tabular}{|c|c|}
\hline Company: & Name \\
\hline AFCC Automotive Fuel Cell Cooperation Corp. & Robert Artibise \\
\hline AFCC Automotive Fuel Cell Cooperation Corp. & Simon Farrington \\
\hline American Trim, LLC & Steve Hatkevich \\
\hline Allegheny Science and Technology & Shaun Onorato \\
\hline Argonne National Lab & John Kopasz \\
\hline Argonne National Lab & Thomas Benjamin \\
\hline Argonne National Lab & Rajesh Ahluwalia \\
\hline Ballard & Bevan Moss \\
\hline Ballard & Andrew Desouza \\
\hline BMW & Zaharias Veziridis \\
\hline Borit NV & Gert Nelissen \\
\hline Dana Corp & Raimund Stroebel \\
\hline Dana Corp & Brian Cheadle \\
\hline Die-Matic Corp. & William Shepard \\
\hline DJW Technology, LLC & Douglas Wheeler \\
\hline EWI & Madeleine Odgaard \\
\hline EWI & Stan Ream \\
\hline Fiat Chrysler Automobiles US & Max Zou \\
\hline Ford Motor Company & Valerie Nelson \\
\hline Ford Motor Company & Mark Ricketts \\
\hline Ford Motor Company & Daniel Wilkosz \\
\hline Ford Motor Company & Shinichi Hirano \\
\hline Freudenberg-NOK Sealing Technologies & Mark Belchuk \\
\hline General Motors & Smuruthi Kamepalli \\
\hline General Motors & Balsu Lakshmanan \\
\hline Giner & Monjid Hamdan \\
\hline GLWN & Patrick Fullenkamp \\
\hline GrafTech AET & Julian Norley \\
\hline GrafTech AET & David Stuart \\
\hline H2 Power Tech, LLC & Harol Koyama \\
\hline H2 Power Tech, LLC & Michael Hicks \\
\hline Hawaii Natural Energy Institute & Jean St-Pierre \\
\hline Hydrogenics Corporation & Rainey Wang \\
\hline Impact Coatings $A B$ & Henrik Ljungcrantz \\
\hline JFE Steel & Toshihiro Kikuchi \\
\hline Los Alamos National Lab & Rod Borup \\
\hline Los Alamos National Lab & Jacob Spendelow \\
\hline Michigan Technological University & Jeffrey Allen \\
\hline National Renewable Energy Laboratory & Judith Vidal \\
\hline Nishimura & Manubu Kinoshita \\
\hline Nishimura & Tatsuo Hisada \\
\hline
\end{tabular}




\begin{tabular}{|l|l|} 
Oak Ridge National Laboratory & David Wood \\
\hline Ohio Fuel Cell Coalition (OFCC) & Pat Valente \\
\hline Ohio Energy \& Advanced Manufacturing Center & Larry Wilkerson \\
\hline Pacific Northwest National Lab & Kevin Simmons \\
\hline Plug Power & Michael Cacioppo \\
\hline Plug Power & Chuck Carlstrom \\
\hline REB Research & Robert Buxbaum \\
\hline Strategic Analysis Inc. & Jennie Huya-Kouadio \\
\hline Strategic Analysis Inc. & Brian James \\
\hline Strategic Analysis Inc. & Yu Yi \\
\hline Terrella Energy Systems Ltd & John Kenna \\
\hline Toyota & Hangfei Jia \\
\hline Toyota & Kuzuyiki Hirata \\
\hline Toyota & Kan Huang \\
\hline Toyota & Kunihiro Yamaura \\
\hline TreadStone Technologies., Inc & Conghua Wang \\
\hline U.S. Department of Energy & Deanna Schenck \\
\hline U.S. Department of Energy & Dimitrios Papageorgopoulos \\
\hline U.S. Department of Energy & Greg Kleen \\
\hline US Department of Energy & Bahman Habibzadeh \\
\hline U.S. Department of Energy & Eric Parker \\
\hline Lincoln Electric & David Guastaferri \\
\hline
\end{tabular}




\section{Appendix B List of Acronyms}

\begin{tabular}{|c|c|}
\hline AES & Auger electron spectroscopy \\
\hline AFCC & Automotive Fuel Cell Cooperation Corp. \\
\hline ANL & Argonne National Laboratory \\
\hline ASR & Area specific resistance \\
\hline AST & Accelerated stress test \\
\hline BDD & boron doped diamond \\
\hline BMC & Bulk molded carbon \\
\hline BP & Bipolar Plate \\
\hline CSS & Coated stainless steel \\
\hline CTE & Coefficient of thermal expansion \\
\hline CVD & Chemical vapor deposition \\
\hline DMFA & Design for manufacturing and assembly \\
\hline DOE & Department of Energy \\
\hline EG & Expanded graphite \\
\hline EGR & Expanded graphite/resin composite \\
\hline FC & Fuel cell \\
\hline FCV & Fuel cell vehicle \\
\hline FCTO & Fuel Cell Technologies Office \\
\hline GDL & Gas diffusion layer \\
\hline GM & General Motors \\
\hline ICE & Internal combustion engine \\
\hline ICP & Inductively coupled plasma \\
\hline ICR & Interfacial contact resistance \\
\hline IEA & International Energy Agency \\
\hline kg & kilogram \\
\hline kW & kilowatt \\
\hline $\mathrm{kW}_{\mathrm{e}}$ & kilowatt electric \\
\hline$k W_{\text {net }}$ & kilowatt net \\
\hline
\end{tabular}




$\begin{array}{ll}\text { LANL } & \text { Los Alamos National Laboratory } \\ \text { MEA } & \text { Membrane electrode assembly } \\ \text { MHE } & \text { Material handling equipment } \\ \text { OEM } & \text { Original equipment manufacturer } \\ \text { ORNL } & \text { Oak Ridge National Laboratory } \\ \text { PBI } & \text { poly benzimidizole } \\ \text { PECVD } & \text { Plasma-enhanced chemical vapor deposition } \\ \text { PEM } & \text { Proton exchange membrane or polymer electrolyte membrane } \\ \text { PGR } & \text { particulate graphite/resin composite } \\ \text { Ppm } & \text { Parts per million } \\ \text { PSI } & \text { Pounds per square inch } \\ \text { PVD } & \text { Physical vapor deposition } \\ \text { R\&D } & \text { Research and Development } \\ \text { RH } & \text { Relative humidity } \\ \text { SA } & \text { Strategic Analysis, Inc. } \\ \text { SS } & \text { Stainless steel } \\ \text { TRL } & \text { Technology readiness level } \\ \text { UV } & \text { Ultra-violet }\end{array}$




\section{Argonne}

Chemical Sciences and Engineering Division

Argonne National Laboratory

9700 South Cass Avenue, Bldg. 241

Argonne, IL 60439

www.anl.gov

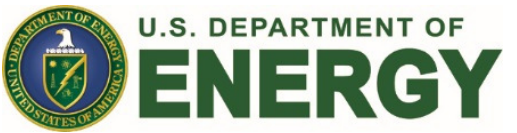

Argonne National Laboratory is a U.S. Department of Energy

laboratory managed by UChicago Argonne, LLC 